\title{
Effect of Deformation Temperature on Microstructure Evolution and Mechanical Properties of Low-Carbon High-Mn Steel
}

\author{
Adam Grajcar (D), Aleksandra Kozłowska (D, Santina Topolska, and Mateusz Morawiec $i$ \\ Institute of Engineering Materials and Biomaterials, Silesian University of Technology, 18a Konarskiego Street, 44-100 Gliwice, \\ Poland \\ Correspondence should be addressed to Adam Grajcar; adam.grajcar@polsl.pl
}

Received 31 May 2017; Accepted 11 December 2017; Published 30 January 2018

Academic Editor: Akihiko Kimura

Copyright ( 92018 Adam Grajcar et al. This is an open access article distributed under the Creative Commons Attribution License, which permits unrestricted use, distribution, and reproduction in any medium, provided the original work is properly cited.

This work addresses the influence of deformation temperature in a range from $-40^{\circ} \mathrm{C}$ to $200^{\circ} \mathrm{C}$ on the microstructure evolution and mechanical properties of a low-carbon high-manganese austenitic steel. The temperature range was chosen to cope at the time during sheet processing or car crash events. Experimental results show that yield stress and ultimate tensile strength gradually deteriorate with an increase in the tensile testing temperature. The dominant mechanism responsible for the strain hardening of steel changes as a function of deformation temperature, which is related to stacking fault energy (SFE) changes. When the deformation temperature rises, twinning decreases while a role of dislocation slip increases.

\section{Introduction}

Among new steel grades developed for application to car bodies [1-5], high-manganese austenitic steels are attractive materials for the automotive industry because of their unique combination of high strength, ductility, and formability. High-manganese steels are characterized by a high work-hardening rate resulting from TRIP (transformationinduced plasticity), TWIP (twinning-induced plasticity), or SIP (shear-induced plasticity) effects [6,7]. A lot of reports concerning the mechanical behavior of high-Mn TRIP or TWIP steels have already been available in the literature. Most of them characterize the influence of heat treatment parameters on microstructure, mechanical properties [8-11], and corrosion behavior of the steels $[12,13]$.

The dominant mechanism of strengthening occurring in these steels strongly depends on the chemical composition, particularly on carbon, manganese, aluminum, and silicon contents. The deformation mechanism depends also on stacking fault energy, strain rate, and temperature. TRIP effect is dominant when SFE is lower than $25 \mathrm{~mJ} / \mathrm{m}^{2}$-some fraction of austenite transforms into $\varepsilon$ or $\alpha^{\prime}$ martensites. When SFE value is in a range of $25-60 \mathrm{~mJ} / \mathrm{m}^{2}$, deformation twins occur (TWIP effect). If SFE value is higher than
$60 \mathrm{~mJ} / \mathrm{m}^{2}$, the steel is strengthened mostly by work hardening. Aluminum strongly increases SFE, whereas silicon causes an opposite effect [14-16].

Deformation temperature changes affect significantly the SFE, which in turn influences the character of the hardening. Shterner et al. reported [17] that the increase of deformation temperature of the $\mathrm{Fe}-0.6 \mathrm{C}-18 \mathrm{Mn}-1 \mathrm{Al}$ TWIP steel caused a decrease of yield strength, ultimate tensile strength, and total and uniform elongation. The highest mechanical properties of the TWIP steel were detected at room temperature. They decrease gradually with the increase in deformation temperature. They also reported [17] that the work-hardening behavior was attributed to complex dynamic strain-induced microstructural changes including dynamic recovery, dislocation dissociation, stacking fault formation, mechanical twinning, and dynamic strain aging.

Asghari et al. [18] classified the strengthening mechanisms depending on the characteristic temperature regimes in unidirectional compression tests: $25-300^{\circ} \mathrm{C}, 300-700^{\circ} \mathrm{C}$, and $700-1000^{\circ} \mathrm{C}$. The $\mathrm{Fe}-0.07 \mathrm{C}-18 \mathrm{Mn}-2 \mathrm{Si}-2 \mathrm{Al}$ steel showed transformation-induced plasticity effect (TRIP effect) as the major deformation mechanism from $25^{\circ} \mathrm{C}$ to $200^{\circ} \mathrm{C}$, whereas deformation twinning (TWIP effect) started from $200^{\circ} \mathrm{C}$ to $300^{\circ} \mathrm{C}$. Above $700^{\circ} \mathrm{C}$ the dynamic restorations, recovery and 
TABLE 1: Chemical composition of the investigated steel (wt.\%).

\begin{tabular}{lccccccccc}
\hline $\mathrm{C}$ & $\mathrm{Mn}$ & $\mathrm{Si}$ & $\mathrm{Al}$ & $\mathrm{S}$ & $\mathrm{P}$ & $\mathrm{Nb}$ & $\mathrm{Ti}$ & $\mathrm{N}$ & $\mathrm{O}$ \\
\hline 0.065 & 26.00 & 3.08 & 2.87 & 0.013 & 0.002 & 0.034 & 0.010 & 0.0028 & 0.0006 \\
\hline
\end{tabular}

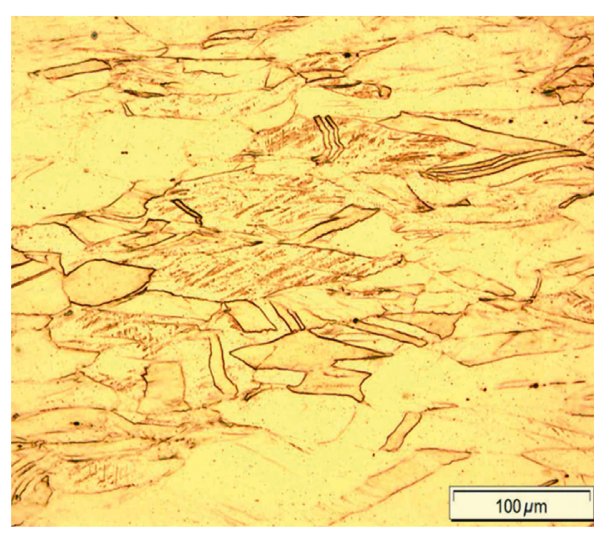

(a)

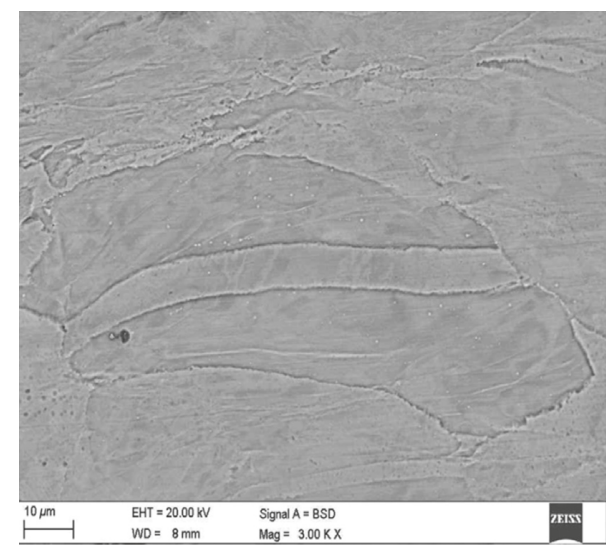

(b)

FIgure 1: Optical micrograph (a) and SEM image (b) of the X6MnSiAlNbTi26-3-3 steel before tensile test.

recrystallization play a key role in microstructural evolution of the experimental steel in accordance with the diminishing SFE. Similar results have been shown by Salas-Reyes et al. [19] for the Fe-0.1C-21Mn-2.5Si-1.6Al steel during compression tests in a temperature range of $25^{\circ} \mathrm{C}$ to $1000^{\circ} \mathrm{C}$. The local composition of steel may be changed during hot deformation, for instance due to the strain-induced precipitation or decomposition, thereby resulting in SFE changes [19].

Eskandari et al. [20] studied the hot ductility behavior of the Fe-0.45C-22Mn-1.5Al-1.5Si steel in uniaxial hot tensile tests in the temperature range of $700-1100^{\circ} \mathrm{C}$ under a constant strain rate. They indicated that the peak stress decreases as the temperature increases, from $250 \mathrm{MPa}$ at $700^{\circ} \mathrm{C}$ up to $30 \mathrm{MPa}$ at $1100^{\circ} \mathrm{C}$. The highest ductility was detected at the intermediate temperature range $\left(800-900^{\circ} \mathrm{C}\right)$. It was caused by dynamic recrystallization.

So far, the mechanical behavior of low-carbon high-Mn steels in a temperature range of $20-200^{\circ} \mathrm{C}$ and below room temperature has been investigated rarely [18, 19]. Most publications concern the mechanical properties of highcarbon high-manganese steels at elevated temperatures: $700-1000^{\circ} \mathrm{C}$, which simulate the hot-rolling conditions. Therefore, the aim of this paper is to determine the effect of deformation temperature on the microstructure evolution and mechanical properties of low-carbon high-manganese steel in a temperature range $-40^{\circ} \mathrm{C}$ to $200^{\circ} \mathrm{C}$ that is chosen to cope at the time during sheet stamping or car crashes.

\section{Experimental Procedure}

2.1. Material. The chemical composition of the X6MnSiAlNbTi26-3-3 steel used is given in Table 1. Carbon and manganese are major austenite stabilizers, whereas silicon and aluminum were added for providing solid solution strengthening. Small amounts of $\mathrm{Nb}$ and Ti were added for precipitation strengthening and grain refinement. The chemical composition of steel significantly affects SFE, which is related to the strengthening mechanisms [14-16].

A steel ingot $(25 \mathrm{~kg})$ was prepared by vacuum melting. Then, it was hot-forged using a high-speed hydraulic press with forging pressure of 300 tons in a temperature range from $1200^{\circ} \mathrm{C}$ to $900^{\circ} \mathrm{C}$. The flat bars after forging were hotrolled to a thickness of $4.5 \mathrm{~mm}$. The thermomechanical processing included hot rolling of the flat samples in 3 passes (at temperatures: $1050^{\circ} \mathrm{C}, 950^{\circ} \mathrm{C}$, and $850^{\circ} \mathrm{C}$ ) to a final thickness of $\sim 2 \mathrm{~mm}$ obtained at the finishing rolling temperature of $850^{\circ} \mathrm{C}$. The hot rolling was conducted using a reversible rolling mill at a circumferential speed of rollers of $0.65 \mathrm{~m} \cdot \mathrm{s}^{-1}$. A solution heat treatment at $900^{\circ} \mathrm{C}$ for $20 \mathrm{~min}$ was followed by a rapid water cooling to room temperature.

2.2. Tensile Tests. $2 \mathrm{~mm}$ thick tensile specimens were machined from the hot-rolled sheet along the rolling direction to investigate the effect of the deformation temperature on the microstructure evolution and mechanical properties. The tensile tests were performed at $-40^{\circ} \mathrm{C}, 20^{\circ} \mathrm{C}, 80^{\circ} \mathrm{C}, 140^{\circ} \mathrm{C}$, and $200^{\circ} \mathrm{C}$ at a strain rate of $5 \times 10^{-3} \mathrm{~s}^{-1}$ using an INSTRON 4505 universal testing machine.

2.3. Microstructure Characterization. The microstructural analysis was performed using Zeiss Axio Observer Z1m optical microscope. The microstructural details were revealed with a scanning electron microscope Zeiss SUPRA 25 operating at $20 \mathrm{kV}$. The specimens at the initial state and after tensile tests were mechanically ground with $\mathrm{SiC}$ paper up to 1500 grid, polished with $\mathrm{Al}_{2} \mathrm{O}_{3}$ and then etched using $5 \%$ nital to observe microstructures.

\section{Results and Discussion}

3.1. Microstructural Evolution. Microstructure of the X6MnSiAlNbTi26-3-3 steel in the initial state is shown in 


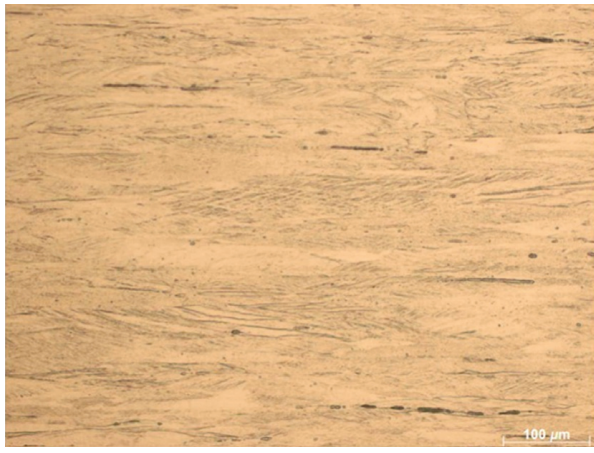

(a)

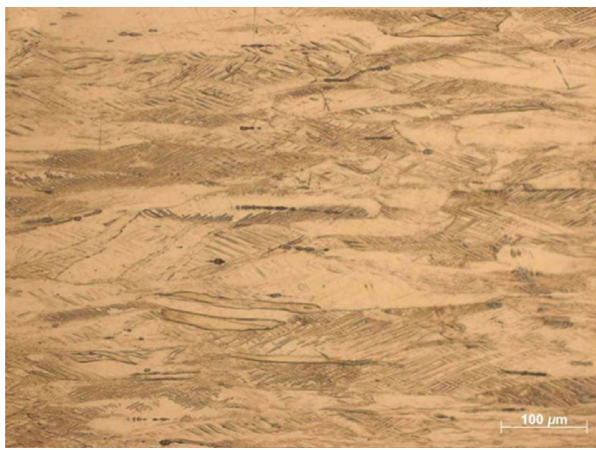

(c)

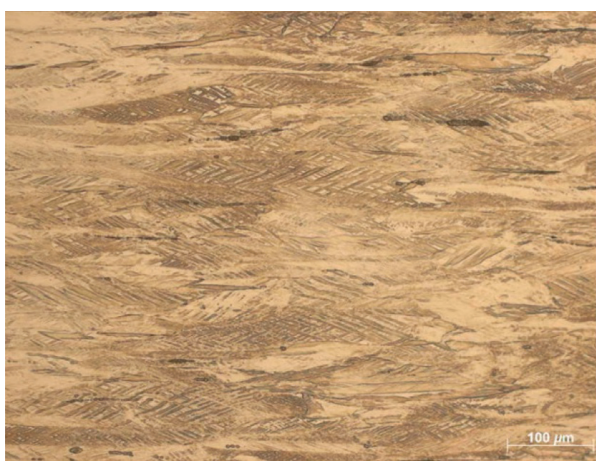

(e)

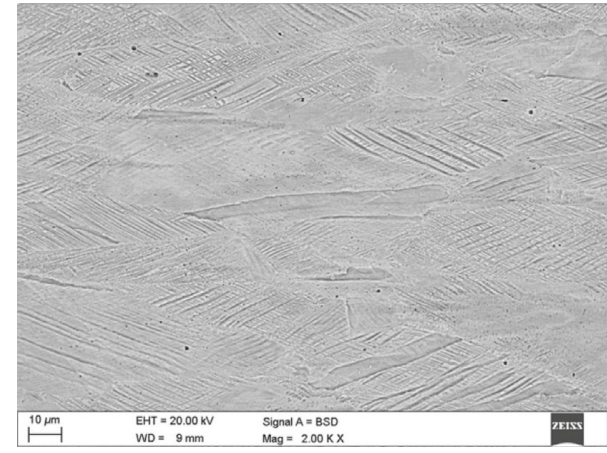

(b)

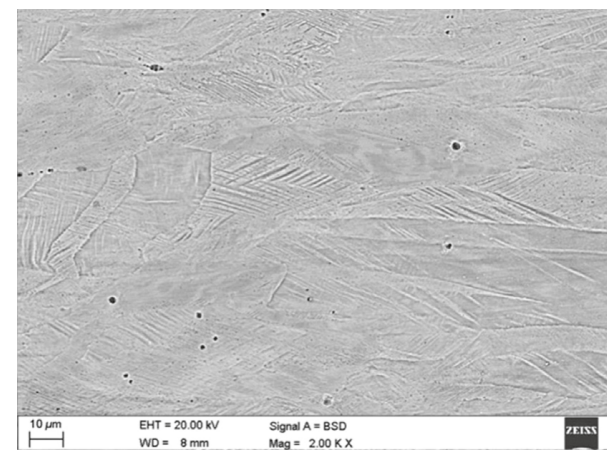

(d)

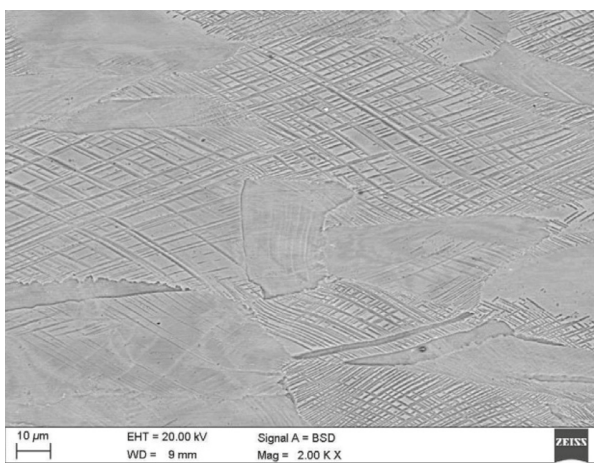

(f)

FIGURE 2: Microstructures of the X6MnSiAlNbTi26-3-3 steel deformed at a temperature of $-40^{\circ}$ ((a) LM; (b) SEM), $80^{\circ} \mathrm{C}((\mathrm{c}) \mathrm{LM}$; (d) SEM), and $200^{\circ} \mathrm{C}$ ((e) LM; (f) SEM) observed by a light microscope (LM), and a scanning electron microscope (SEM).

Figure 1. Austenite grains are relatively coarse and elongated along rolling direction. Annealing twins were also observed.

The results obtained from the tensile tests indicate a relationship among the test temperature, microstructure, and mechanical properties. The microstructure of the steel deformed in a static tensile test at $-40^{\circ} \mathrm{C}$ is characterized by the presence of austenitic grains elongated according to the direction of applied tensile loading. With the reduction of deformation temperature the SFE decreases [18], therefore mechanical twinning occurred as a main strengthening mechanism (Figure 2(a)). The low SFE results in a reduction of stress levels necessary to initiate the twinning process. SEM image revealed also the presence of slip bands (Figure 2(b)). Shterner et al. reported [17] that, in the Fe-0.6C-18Mn$1 \mathrm{Al}$ steel, mechanical twins nucleated at the grain boundaries and then propagated across the grain interior, as the degree of deformation increased. Amount of deformation twins in the microstructure is related to the increasing dislocation density during deformation process. The microstructure of the steel deformed at room temperature is similar to the one obtained at $-40^{\circ} \mathrm{C}$. This concerns the amount of crossing slip lines and bands as wells as numerous deformation twins. The occurrence of the transformationinduced plasticity effect (TRIP) or twinning mechanism (TWIP) is common at relatively low test temperature. Shterner et al. [17] reported that, at a strain level of 0.4 , the volume fraction of mechanical twins reduced from $11.2 \%$ at room temperature to $5 \%$ and $2.9 \%$ at $100^{\circ} \mathrm{C}$ and $200^{\circ} \mathrm{C}$, respectively.

The microstructure of the sample deformed at $80^{\circ} \mathrm{C}$ indicates a dominant role of crossed slip lines and bands (Figures 2(c) and 2(d)). The amount of deformation twins is 
TABLE 2: Mechanical properties of the tensile tested steel at each temperature.

\begin{tabular}{lccccc}
\hline \multicolumn{2}{l}{ Temperature $(\mathrm{T})$} & Tensile strength $(\mathrm{UTS})(\mathrm{MPa})$ & Yield stress $\left(\mathrm{YS}_{0.2}\right)(\mathrm{MPa})$ & $\mathrm{YS}_{0.2} / \mathrm{UTS}$ & Total elongation $(\mathrm{TE})(\%)$ \\
\hline 1 & $-40^{\circ} \mathrm{C}$ & 834 & 577 & 0.69 & 43.4 \\
2 & $20^{\circ} \mathrm{C}$ & 743 & 554 & 0.75 & 43.8 \\
3 & $80^{\circ} \mathrm{C}$ & 676 & 527 & 0.78 & 41.8 \\
4 & $140^{\circ} \mathrm{C}$ & 617 & 511 & 0.83 & 43.4 \\
5 & $200^{\circ} \mathrm{C}$ & 604 & 509 & 0.84 & 22.4 \\
\hline
\end{tabular}

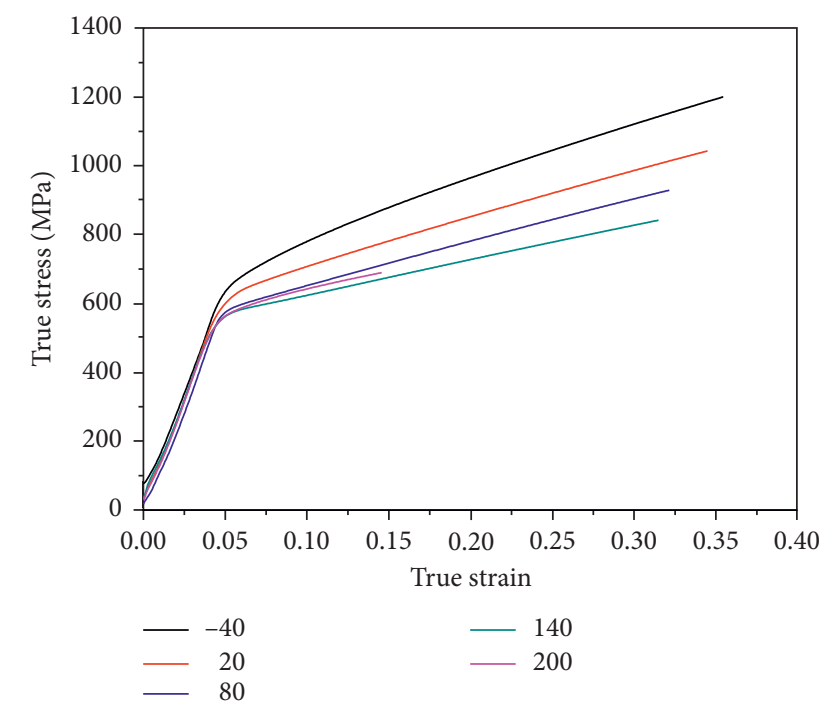

FIgURE 3: True stress-true strain curves in a uniform elongation range of the X6MnSiAlNbTi26-3-3 steel at various deformation temperatures.

smaller than in the samples deformed at $-40^{\circ} \mathrm{C}$ and $20^{\circ} \mathrm{C}$. Increasing the test temperature to $80^{\circ} \mathrm{C}$ results in an increase of SFE, which limits the twinning occurrence. The deformation of the sample at $140^{\circ} \mathrm{C}$ favors dislocation slip as a main deformation mechanism, while the formation of twins is strongly limited. The prevailing mechanism of deformation at $200^{\circ} \mathrm{C}$ appears to be dislocation slip (Figures 2(e) and 2(f)). Chen et al. [21] confirmed that deformation bands can be observed in pancaked austenite deformed in a non-recrystallization region, which bridge the grains by roughly parallel lines. No $\varepsilon$ or $\alpha^{\prime}$ martensites were observed in the temperature range $-40^{\circ} \mathrm{C}$ to $200^{\circ} \mathrm{C}$. Such behavior is typical for steels characterized by SFE $>20 \mathrm{~mJ} / \mathrm{m}^{2}$, resulting from the chemical composition.

3.2. Mechanical Properties. The mechanical properties of the steel tensile tested at each temperature is shown in Table 2, indicating a strong temperature dependence.

Figure 3 shows the true stress-true strain curves in the temperature range of $-40^{\circ} \mathrm{C}$ to $200^{\circ} \mathrm{C}$. The X6MnSiAlNbTi263-3 steel showed the best mechanical properties at $-40^{\circ} \mathrm{C}$, having a tensile strength (UTS) of $834 \mathrm{MPa}$, yield stress (YS) of $577 \mathrm{MPa}$, and total elongation of $43.4 \%$ (Figures 3-5). At $-40^{\circ} \mathrm{C}$, the dominant mechanism responsible for the high strain hardening of the steel is twinning (Figures 2(a) and 2(b)).

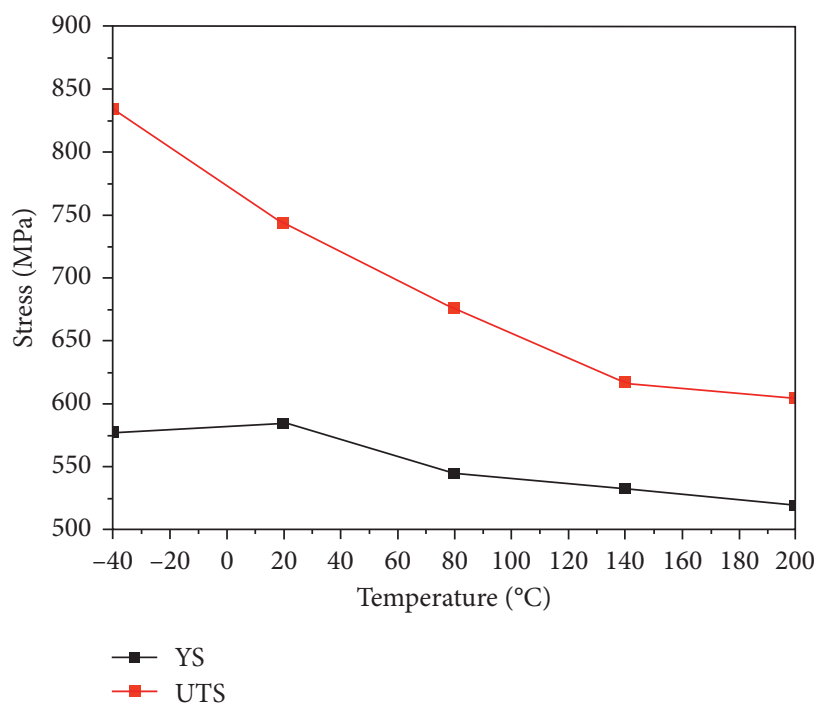

FIgURE 4: Mechanical properties of the X6MnSiAlNbTi26-3-3 steel: yield stress (YS) and ultimate tensile strength (UTS) at various tensile test temperatures.

The YS/UTS ratio in this case is 0.69 , which indicates relatively high strengthening potential (Figure 5).

The steel deformed at $20^{\circ} \mathrm{C}$ is characterized by slightly lower mechanical properties $(\mathrm{YS}=584 \mathrm{MPa}$; UTS $=743 \mathrm{MPa})$ than the one deformed at $-40^{\circ} \mathrm{C}$ (Figure 4). The YS/UTS ratio rises to 0.75 (Figure 5). It shows the gradual lowering of strengthening intensity with the increase of deformation temperature. Total elongation remains at the same level $\sim 43.8 \%$ (Figure 5). The combination of high strength and ductility both at $-40^{\circ} \mathrm{C}$ and at room temperature is mostly related to twinning mechanism. At $80^{\circ} \mathrm{C}$, the mechanical properties decreased: $\mathrm{YS}=527 \mathrm{MPa}$ and UTS $=676 \mathrm{MPa}$ (Figure 4), which is related to a decrease in the density of deformation twins (Figures 2(c) and 2(d)) and a gradual increase of the SFE. The YS/UTS ratio increased to 0.78 (Figure 5). When the temperature increases, the role of slip lines and bands in the plastic deformation increases. However, the reduction of total elongation is relatively small ( $2 \%)$ when compared to the specimen deformed at $20^{\circ} \mathrm{C}$ (Figure 5). Such a small reduction is due to the combination of mechanical twinning and slip and overall high plasticity of the austenite phase.

The specimen deformed at $140^{\circ} \mathrm{C}$ shows further lower strengthening effect than the samples deformed in a lower temperature range (Figure 3). YS and UTS are $511 \mathrm{MPa}$ and $617 \mathrm{MPa}$, respectively. The YS/UTS ratio in this temperature 


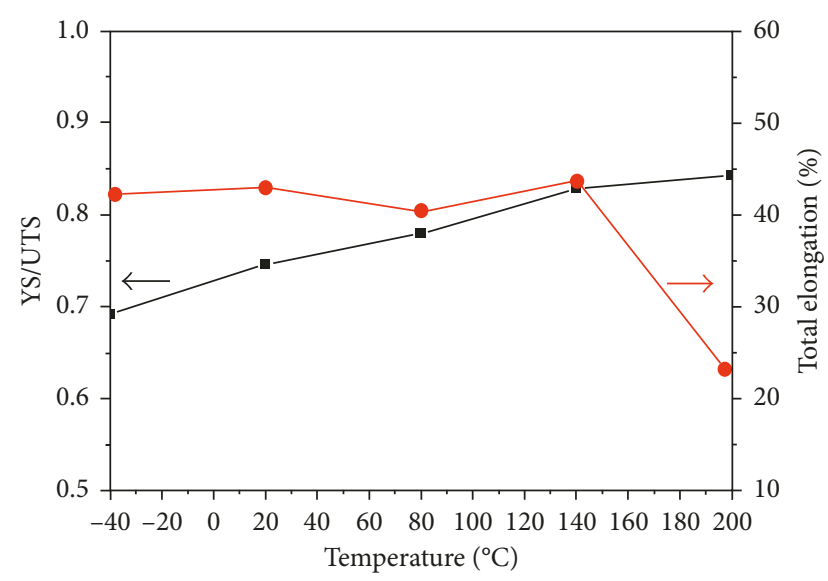

FIGURE 5: YS/UTS ratio (square) and total elongation (circle) of the X6MnSiAlNbTi26-3-3 steel at various tensile test temperatures.

corresponds to 0.83 (Figure 5). It indicates a significant decrease in the intensity of the strengthening. It is also reflected in a slope of the $\sigma-\varepsilon$ curve (Figure 3 ). The temperature of $140^{\circ} \mathrm{C}$ favors dislocation slip as a main deformation mechanism. However, the change of dominant deformation mechanism from twinning to dislocation slip is not still too detrimental for total elongation (43.4\%), but these conditions strongly affect the strength properties.

The mechanical properties determined for the sample deformed at $200^{\circ} \mathrm{C}$ are the lowest compared to the results obtained at the lower temperatures (Table 2). YS and UTS are $509 \mathrm{MPa}$ and $604 \mathrm{MPa}$, respectively (Figure 4), and $\mathrm{YS} / \mathrm{UTS}=0.84$ (Figure 5). The slight slope of the $\sigma-\varepsilon$ curve shown in Figure 3 indicates the minimum intensity of the strengthening. The specimen deformed at $200^{\circ} \mathrm{C}$ is characterized by a rapid decrease of plasticity expressed as the lowest total elongation $=22.4 \%$ (Figure 5). The plasticity is almost twice lower when compared to the other samples. The significant decrease of plasticity is due to disappearance of mechanical twinning and increased importance of diffusion processes activated at elevated temperatures.

Asghari et al. [18] reported that the mechanical twinning occurring inside the austenite grains by the variation of deformation temperature strongly affects the mechanical behavior of steel. The mechanical twins subdivide the austenite grains and reduce the dislocations mean free path. Therefore, the twin boundaries act as strong barriers to dislocation motion. Hence, higher mechanical properties reflect the occurrence of mechanical twinning. Mechanical twins were observed in the microstructures of samples deformed in the temperature range: $-40^{\circ} \mathrm{C}-80^{\circ} \mathrm{C}$ (Figures $2(\mathrm{a})-2(\mathrm{~d})$ ). Eskandari et al. [20] observed mechanical twins in a temperature range $150^{\circ} \mathrm{C}-$ $600^{\circ} \mathrm{C}$ during compression of the Fe-0.1C-21Mn-2.5Si-1.6Al$0.02 \mathrm{Nb}-0.02 \mathrm{Ti}-0.01 \mathrm{~V}$ steel. Shterner et al. [17] showed that mechanical properties such as YS and UTS of the Fe-0.6C$18 \mathrm{Mn}-1 \mathrm{~A}$ steel decreased with increasing temperature of tensile test: from YS $=500 \mathrm{MPa}$ and UTS $=1000 \mathrm{MPa}$ at room temperature to $\mathrm{YS}=430 \mathrm{MPa}$ and $\mathrm{UTS}=840 \mathrm{MPa}$ at $200^{\circ} \mathrm{C}$. Total elongation was high between $20^{\circ} \mathrm{C}$ and $100^{\circ} \mathrm{C}(60-65 \%)$ and gradually decreased above $100^{\circ} \mathrm{C}$ (e.g., $47 \%$ at $200^{\circ} \mathrm{C}$ ).

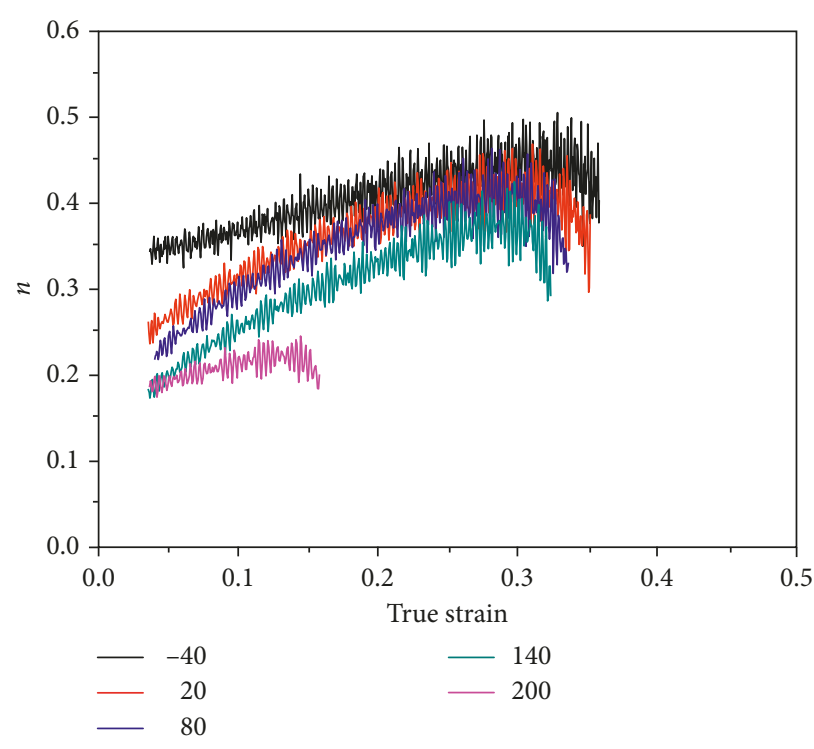

FIGURE 6: Work-hardening exponent $n$ changes as a function of true strain at various tensile test temperatures.

The steel shows the TWIP effect most intensively at $-40^{\circ} \mathrm{C}$. The mechanical twins were detected up to $\sim 80^{\circ} \mathrm{C}$. Asghari et al. [18] and Eskandari et al. [20] observed the TWIP effect in a temperature range $200-300^{\circ} \mathrm{C}$. It seems that the steel shows an optimal TWIP effect at lower temperatures. In order to obtain a better TWIP effect at room temperature and at increased temperatures, some modification of the chemical composition of the steel would be required. It is expected that TWIP effect could be enhanced by reducing the aluminum and manganese contents, when the SFE at room temperature would be high.

The mechanical twinning is believed to significantly influence the work hardening of high-Mn steels. Presence of mechanical twins in the microstructure blocks the movement of dislocation glide $[17,21]$. The gradual increase in the amount of mechanical twins and the increase of deformation level prevent the localization of deformation. The workhardening exponent $n$ gradually rises as the degree of deformation increases (Figure 6). The highest value of $n$ exponent $=0.46$ was obtained at $-40^{\circ} \mathrm{C}$ (Figure 7 ). It is related to the dominant character of twinning mechanism, which decreases with increasing the deformation temperature. With increasing test temperature, the strengthening potential expressed as $n$ values gradually decreases. Shterner et al. [17] suggested that the interactions of glide dislocations with stacking faults have greater contributions to the workhardening behavior (plateau region) compared with the mechanical twinning at room temperature. The present steel has a relatively small grain size (high grain boundary area), which significantly enhances the interactions between the dislocations and the grain boundaries. However, at $200^{\circ} \mathrm{C}$ grain boundaries start to lose their reinforcing character due to the initiation of diffusion processes.

The deformation temperature strongly affects the workhardening rate (Figure 8). The shape of the curves is typical; that is, the $\mathrm{d} \sigma / \mathrm{d} \varepsilon$ values decrease rapidly at an initial range of 


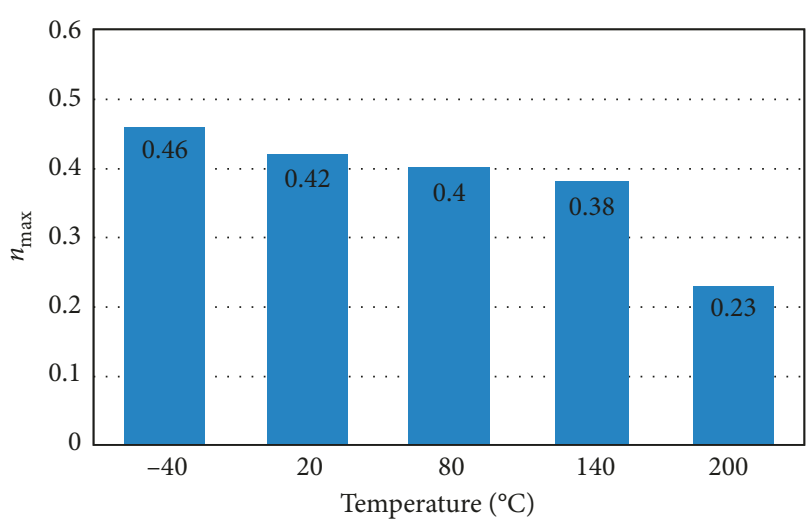

Figure 7: Maximum values of work-hardening exponent $n_{\max }$ at various tensile test temperatures.

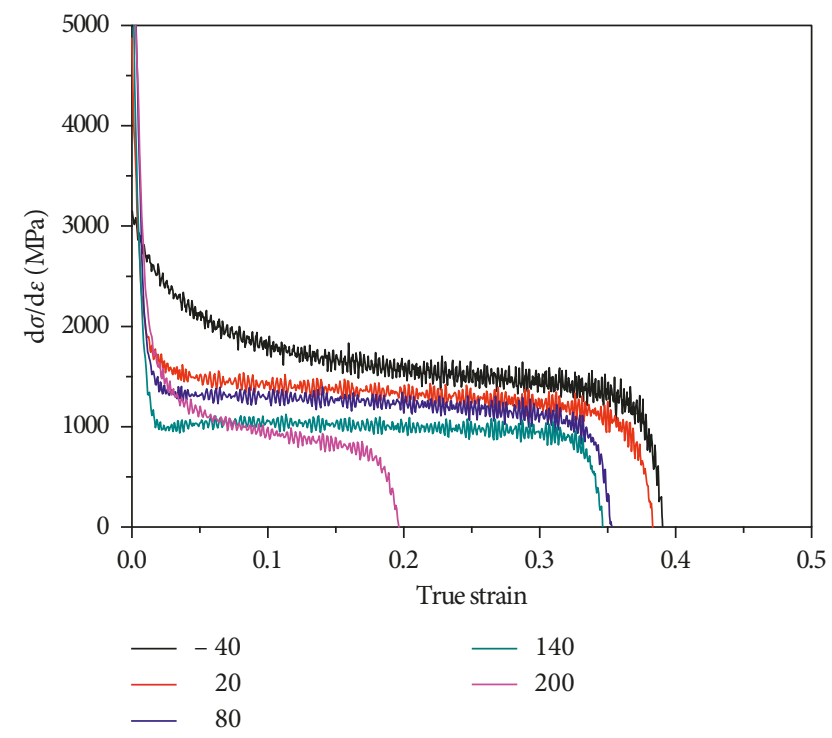

FIGURE 8: Work-hardening rate as a function of true strain at different tensile test temperatures.

deformation. Then, the work-hardening rate stabilizes at a constant level for the samples deformed between $-40^{\circ} \mathrm{C}$ and $140^{\circ} \mathrm{C}$ due to the combined occurrence of deformation twinning and deformation slip. A various level of the deformation twinning at various temperatures is reflected in a different constant value of $\mathrm{d} \sigma / \mathrm{d} \varepsilon$. It is circa $1900-1800 \mathrm{MPa}$ for the temperature of $-40^{\circ} \mathrm{C}$ and about $1000 \mathrm{MPa}$ for a sample deformed at $140^{\circ} \mathrm{C}$. The different behavior is registered for a sample deformed at the highest deformation temperature, where a continuous decrease of the workhardening rate can be observed due to a lack of deformation twinning.

\section{Conclusions}

The present study investigated the effect of deformation temperature on the microstructure evolution and mechanical properties of low-carbon high-Mn steel. The steel showed the best mechanical properties at $-40^{\circ} \mathrm{C}$ due to the
TWIP effect. Yield stress and ultimate tensile strength gradually deteriorated with an increase in the deformation temperature from $-40^{\circ} \mathrm{C}$ to $200^{\circ} \mathrm{C}$. The reduction of the mechanical properties was related to the decrease in the contribution of twinning, whereas that of dislocation slip increased. The significant reduction of the plasticity occurred at $200^{\circ} \mathrm{C}$ due to a lack of mechanical twinning, and diffusion processes activated at elevated temperatures.

The friction occurring during steel sheet forming or a crash event can lead very often to an increase in the temperature of a formed metal piece to $\sim 100^{\circ} \mathrm{C}$. To maximize the potential application of the high-Mn steel, its chemical composition should be modified to reduce its SFE in a desired temperature range from $20^{\circ} \mathrm{C}$ to $100^{\circ} \mathrm{C}$. As a result, the optimum window of mechanical properties would shift to higher temperatures. One of the options is to reduce the aluminum content.

\section{Conflicts of Interest}

The authors declare that there are no conflicts of interest regarding the publication of this paper.

\section{References}

[1] E. I. Galindo-Nava and P. E. J. Rivera-Díaz-del-Castillo, "Understanding martensite and twin formation in austenitic steels: a model describing TRIP and TWIP effects," Acta Materialia, vol. 128, pp. 120-134, 2017.

[2] A. Grajcar and R. Kuziak, "Softening kinetics in Nbmicroalloyed TRIP steels with increased Mn content," Advanced Materials Research, vol. 314-316, pp. 119-122, 2011.

[3] H. Jirkova, L. Kucerova, D. Aisman, and B. Masek, "Optimization of the Q-P process parameters for low alloyed steels with $0.2 \%$ C," Archives of Metallurgy and Materials, vol. 59, no. 3, pp. 1205-1210, 2014.

[4] R. A. Mesquita, R. Schneider, K. Steineder, L. Samek, and E. Arenholz, "On the austenite stability of a new quality of twinning induced plasticity steel, exploring new ranges of $\mathrm{Mn}$ and C," Metallurgical and Materials Transactions A, vol. 44, no. 9, pp. 4015-4019, 2013.

[5] K. Steineder, R. Schneider, D. Krizan, C. Beal, and C. Sommitsch, "Investigation on the microstructural evolution in a medium-Mn steel (X10Mn5) after intercritical annealing," HTM Journal of Heat Treatment and Materials, vol. 70, no. 1, pp. 19-25, 2015.

[6] R. Kuziak, R. Kawalla, and S. Waengler, "Advanced high strength steels for automotive industry," Archives of Civil and Mechanical Engineering, vol. 8, no. 2, pp. 103-117, 2008.

[7] B. C. De Cooman, K. Chin, and J. Kim, High-Mn TWIP Steels for Automotive Applications, Intech, Open Access Publisher, Rijeka, Croatia, 2011.

[8] L. A. Dobrzański, M. Czaja, W. Borek, K. Labisz, and T. Tański, "Influence of hot-working conditions on a structure of X11MnSiAl17-1-3 steel for automotive industry," International Journal of Materials and Product Technology, vol. 51, no. 3, pp. 264-280, 2015.

[9] M. Jabłońska and A. Śmiglewicz, "A study of mechanical properties of high manganese steels after different rolling conditions," Metalurgija, vol. 54, no. 4, pp. 619-622, 2015.

[10] J. Kowalska, W. Ratuszek, M. Witkowska, A. Zielińska-Lipiec, and M. Kowalski, "Microstructure and texture evolution 
during cold-rolling in the Fe-23Mn-3Si-3Al alloy," Archives of Metallurgy and Materials, vol. 60, no. 3, pp. 1789-1794, 2015.

[11] X. Yuana, L. Chena, Y. Zhao, H. Di, and F. Zhu, "Influence of annealing temperature on mechanical properties and microstructures of a high manganese austenitic steel," Journal of Materials Processing Technology, vol. 217, pp. 278-285, 2015.

[12] A. Grajcar, A. Płachcińska, S. Topolska, and M. Kciuk, "Effect of thermomechanical treatment on the corrosion behavior of $\mathrm{Si}$ - and Al- containing high-Mn austenitic steel with $\mathrm{Nb}$ and Ti micro-additions," Materiali in Tehnologije, vol. 49, no. 6 , pp. 889-894, 2015.

[13] A. Grajcar, M. Kciuk, S. Topolska, and A. Płachcińska, "Microstructure and corrosion behavior of hot-deformed and cold-strained high-Mn steels," Journal of Materials Engineering and Performance, vol. 25, no. 6, pp. 2245-2254, 2016.

[14] E. Mazancova and K. Mazanec, "The stacking fault energy evaluation of the TWIP and TRIPLEX alloys," Kovove Materialy, vol. 47, no. 6, pp. 353-358, 2009.

[15] D. Kuc, E. Hadasik, G. Niewielski et al., "Structural and mechanical properties of laboratory rolled steels high-alloyed with manganese and aluminium," Archives of Civil and Mechanical Engineering, vol. 12, no. 3, pp. 312-317, 2012.

[16] J. S. Jeong, W. Woo, K. H. Oh, S. K. Kwon, and Y. M. Koo, "In situ neutron diffraction study of the microstructure and tensile deformation behavior in $\mathrm{Al}$-added high manganese austenitic steels," Acta Materialia, vol. 60, no. 5, pp. 22902299, 2012.

[17] V. Shterner, I. B. Timokhina, and H. Beladi, "On the workhardening behaviour of a high manganese TWIP steel at different deformation temperatures," Materials Science and Engineering A, vol. 669, pp. 437-446, 2016.

[18] A. Asghari, A. Zarei-Hanzaki, and M. Eskandari, "Temperature dependence of plastic deformation mechanisms in a modified transformation-twinning induced plasticity steel," Materials Science and Engineering A, vol. 579, pp. 150-156, 2013.

[19] A. E. Salas-Reyes, I. Mejía, A. Bedolla-Jacuinde, A. Boulaajaj, J. Calvo, and J. M. Cabrera, "Hot ductility behavior of high$\mathrm{Mn}$ austenitic Fe-22Mn-1.5Al-1.5Si-0.45C TWIP steels microalloyed with Ti and V," Materials Science and Engineering A, vol. 611, pp. 77-89, 2014.

[20] M. Eskandari, A. Zarei-Hanzaki, J. A. Szpunar, M. A. Mohtadi-Bonab, A. R. Kamali, and M. NazarianSamani, "Microstructure evolution and mechanical behavior of a new microalloyed high Mn austenitic steel during compressive deformation," Materials Science and Engineering A, vol. 615, pp. 424-435, 2014.

[21] L. Chen, H. Kim, S. K Kim, and B. C. De Cooman, "Localized deformation due to Portevin-Le Chatelier effect in $18 \mathrm{Mn}-$ 0.6C TWIP austenitic steel," ISIJ International, vol. 47, no. 12, pp. 1804-1812, 2007. 


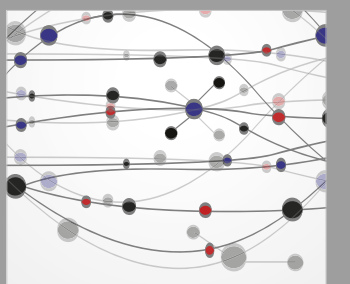

The Scientific World Journal
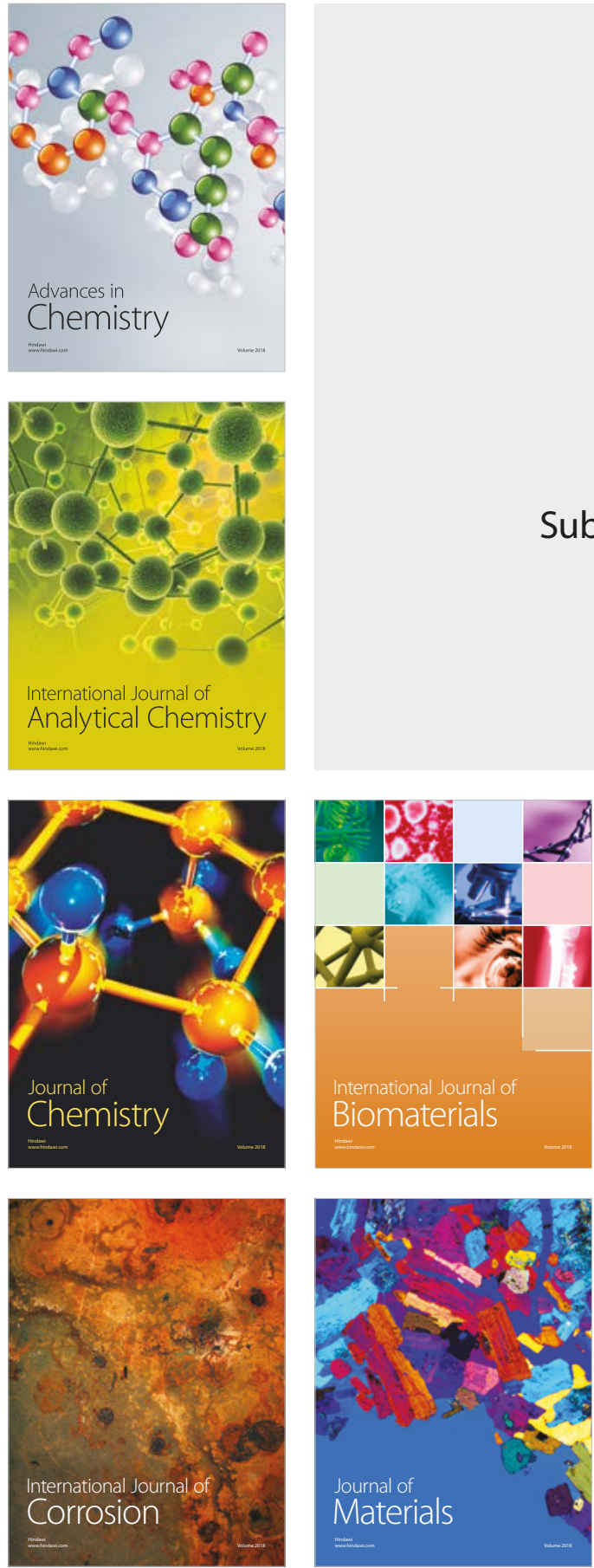

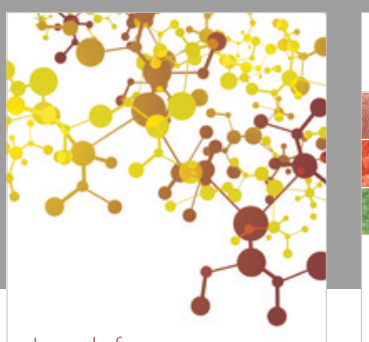

Journal of

Applied Chemistry
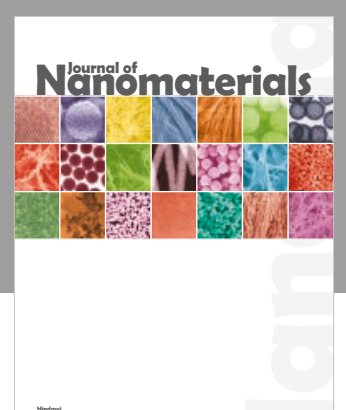

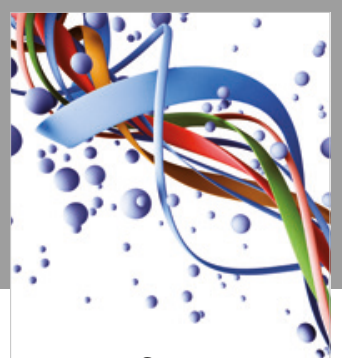

Scientifica

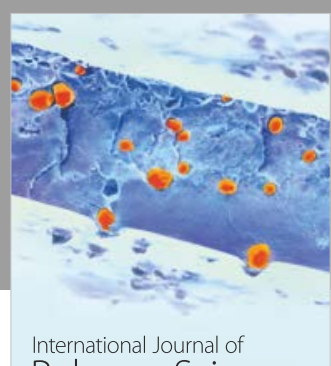

Polymer Science

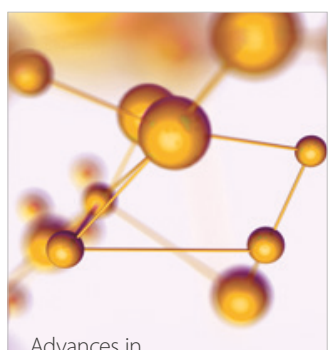

Physical Chemistry
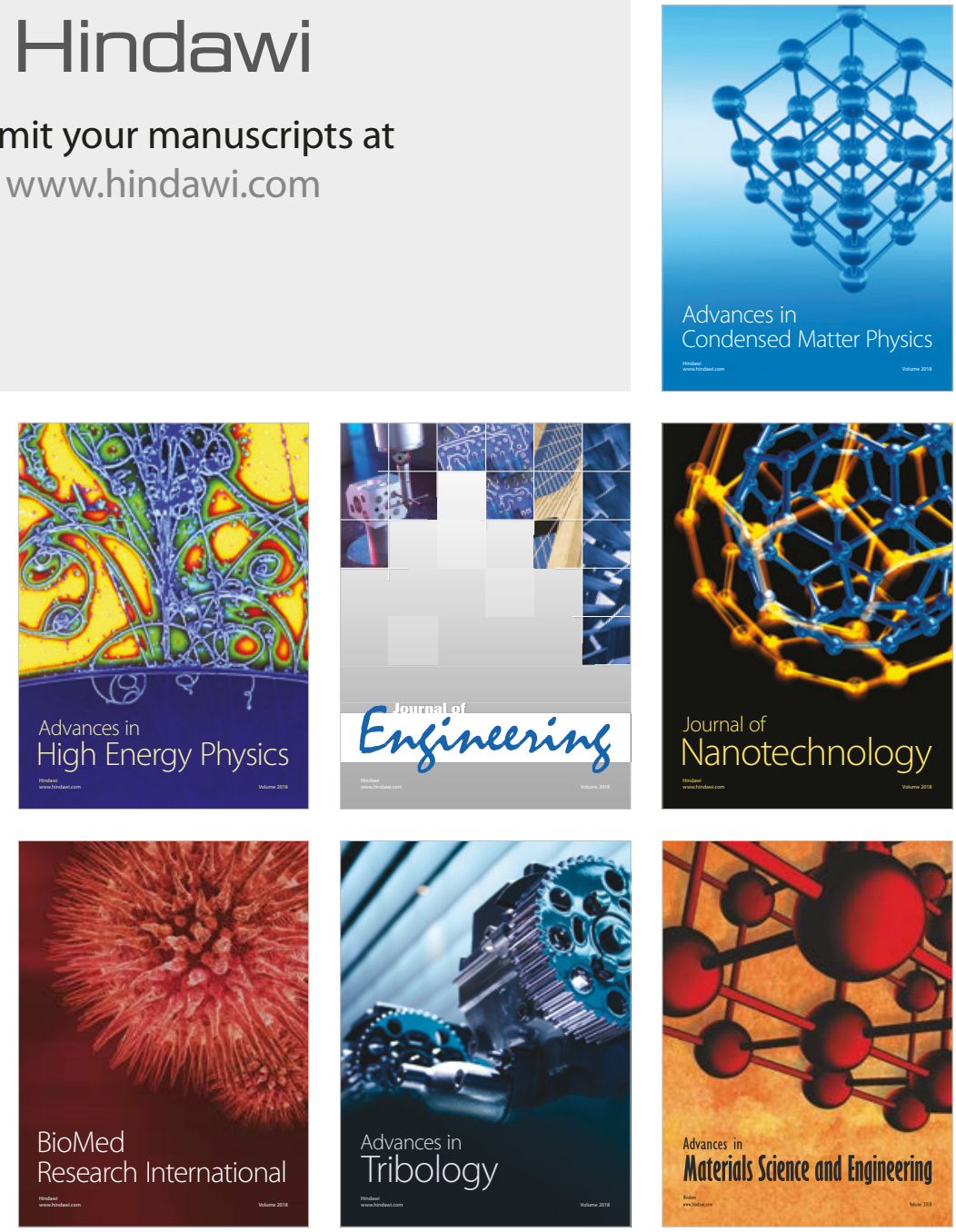